MATEC Web of Conferences 9, 01004 (2013)

DOI: $10.1051 /$ matecconf/20130901004

(C) Owned by the authors, published by EDP Sciences, 2013

\title{
Fire safety of wooden balconies, facades and eaves
}

\section{Esko Mikkola}

\author{
KK-Fireconsult Ltd, Espoo, Finland
}

\begin{abstract}
Fire safety aspects and requirements of wooden balconies and access balconies have been studied covering the following countries: Austria, Switzerland, Germany, Finland, France, Norway, Sweden, UK and Canada. The analysis concerned 3-8 storey apartment buildings with timber frames (and to some extent also office buildings), including the following topics: Assumptions on fire exposure, fire resistance requirements, reaction to fire requirements, possible requirements concerning protective means and use of balconies as exit routes in a fire situation.
\end{abstract}

The performance of different types of protection of eaves under facade fires were analysed to find safe and practical solutions. The different types of eaves include totally closed (EI 30) eaves, use of fire dampers and closing valves, ventilated eaves with specific fire preventive construction and compensation of requirements for eaves by additional requirements for roofs (case-specific applications).

\section{FIRE SAFETY REQUIREMENTS FOR BALCONIES AND ACCESS BALCONIES}

Requirements for 3-8 storey apartment buildings (partly also for office buildings) with wooden frames were reviewed by sending a questionnaire to national experts of fire safety. The questionnaire included the following topics:

- Assumptions on fire loads

- Fire resistance requirements

- Reaction to fire requirements

- Requirements for sprinklers and protective coverings

- Effects of glazing in balconies

- Use of balconies as exits.

Answers to the questionnaire were quite comprehensive. Some of the respondents gave answers only to some parts of the topics, and for these cases information was complemented with information available from other sources and earlier studies.

\section{Assumed fire loads}

In many of the countries of this study there are no specific assumptions for fire loads in buildings. However, in some countries Eurocode (EN 1991-1-2) [1] values are used as a basis of fire load design values with nationally modified values (Table 1). Effect of sprinkler systems may be taken into account by means of reduction factors (as in Eurocode).

Usually it is not explicitly specified whether a load-bearing timber frame is included in the fire load. In Sweden, a principle on "protected energy" may be applied if the probability of contribution to fire is low and it has to be specified, e.g. by failure frequency.

This is an Open Access article distributed under the terms of the Creative Commons Attribution License 2.0, which permits unrestricted use, distribution, and reproduction in any medium, provided the original work is properly cited. 


\section{MATEC Web of Conferences}

Table 1. Assumed fire load values for apartment and office buildings.

\begin{tabular}{|l|l|l|l|l|l|}
\hline Fire load (MJ/m $\mathbf{m}^{\mathbf{2}}$ ) & D & FI & N & S & UK \\
\hline Apartment building & 1085 & 600 & $400 *$ & 800 & 870 \\
Sprinklered building & & & & 488 & 570 \\
\hline Office building & 584 & 600 & $400 *$ & 520 & 522 \\
Sprinklered building & & & & 317 & 342 \\
\hline
\end{tabular}

* No specific definition. Movable fire load can be assumed to be $<400 \mathrm{MJ} / \mathrm{m}^{2}$.

Table 2. Fire resistance requirements for walls, floors, balconies and access balconies (timber framed apartment buildings).

\begin{tabular}{|c|c|c|c|c|c|c|c|c|c|}
\hline Fire resistance & $\mathbf{A}$ & $\mathbf{C H}$ & D & $\mathbf{F}$ & FI & $\mathbf{N}$ & $\mathbf{S}$ & UK & CAN \\
\hline 3-4 floors & & & & & & & & & \\
\hline Walls and floors & R60 & R60 & R60 & R60 & R60 & R60 & R60 & R60 & $\mathrm{R} 60^{6)}$ \\
\hline -Sprinklered & R60 & $\mathrm{R} 30$ & R60 & R60 & R60 & R60 & R60 & R60 & $\mathrm{R} 60^{6)}$ \\
\hline 5-8 floors & & & & & & & & & \\
\hline Walls and floors & (A2 req) & $\mathrm{R} 60^{2)}$ & $\mathrm{R} 60^{3)}$ & R60 & R60 & 4) & $\mathrm{R} 90^{5)}$ & R90 & (A2 req) \\
\hline - Sprinklered & R90 & $\left.\mathrm{R} 60^{2}\right)$ & $\mathrm{R} 60^{3)}$ & R60 & R60 & 4) & R60 & R90 & (A2 req) \\
\hline Balconies 3-4 floors & $\mathrm{R} 30^{\mathrm{I})}$ & R60 & R0 & & R30 & R60 & R30 & R0 & 7) \\
\hline - Sprinklered & $\mathrm{R} 30^{1)}$ & R30 & R0 & & R30 & R60 & R30 & R0 & 7) \\
\hline Access bal. 3-4 floors & R60 & R60 & R60 & & R60 & R60 & R30 & R60 & $\mathrm{R} 60^{6)}$ \\
\hline - Sprinklered & R60 & R30 & R60 & & R60 & R60 & R30 & R60 & R60 \\
\hline Balconies 5-8 floors & (A2 req) & R602) & $\mathrm{R} 0^{3)}$ & & R30 & R60 & R30 & R0 & (A2 req) \\
\hline Access bal. 5-8 floors & (A2 req) & $\mathrm{R} 60^{2)}$ & $\mathrm{R} 60^{3)}$ & & R60 & R60 & R30 & R90 & (A2 req) \\
\hline
\end{tabular}

1) No requirements if 3 floors.

2) Maximum 6 floors.

3) Maximum 5 floors.

4) No table values, verification required.

5) R60 for floors.

6) Maximum 3 floors. Also R45 may fulfil requirements.

7) No R requirement if not used as an exit.

\section{Fire resistance requirements of load-bearing structures}

In timber framed apartment buildings the fire resistance requirement is usually R60 for walls and floors up to 8 floors (Table 2). In some countries for buildings with more than 3 or 4 floors the requirement is R90 or even non-combustible (at least A2 class) load bearing structures are required.

For balconies fire resistance requirements vary between R0 and R60, and the requirements are usually the same for sprinklered and non-sprinklered buildings. For access balconies fire resistance requirements are generally more stringent than for balconies, ranging from R30 to R90. There are generally no differences in requirements between apartment and office buildings.

\section{Reaction to fire requirements}

Use of untreated (= no fire retardant treated) wood is usually possible on facades up to $4-7$ floors (see Table 3) or even more if relevant proof has been demonstrated (e.g. with large scale testing). On the first floor non-combustible products may be required. Reaction to fire requirement of balconies is commonly D (or C) level. For balcony floors typical requirement is $\mathrm{D}_{\mathrm{FL}}$. For access balconies reaction to fire requirements are generally more stringent (walls and ceilings most often at least B level) than for 
balconies reflecting the use as an exit way. There are generally no differences in requirements between apartment and office buildings.

Table 3. Reaction to fire requirements for facades, balconies and access balconies in apartment buildings with at least 3 floors (Maximum number of floor are the following: 7 floors in Austria, 8 in Finland and 4 in Norway and Canada).

\begin{tabular}{|c|c|c|c|c|c|c|c|c|}
\hline Reaction to fire & $\mathbf{A}$ & $\mathbf{C H}$ & D & FI & $\mathbf{N}$ & $\mathbf{S}$ & UK & CAN \\
\hline $\begin{array}{l}\text { Facades ( } \geq 3 \text { floors) } \\
\text { General } \\
\text { Sprinklered building }\end{array}$ & $\begin{array}{l}\text { D-s3,d1 } \\
\text { D-s3,d1 }\end{array}$ & & $\begin{array}{l}\text { C-s3,d1 } \\
\text { C-s3,d1 }\end{array}$ & D-s2, $\mathrm{d}^{2)}$ & $\begin{array}{l}\text { D-s3,d0 } \\
\text { D-s3,d0 }\end{array}$ & $\begin{array}{l}3,4) \\
\text { D-s } 1, \mathrm{~d} 0^{4)}\end{array}$ & $\begin{array}{l}\text { B-s3,d2 } \\
\text { B-s3,d2 }\end{array}$ & $\begin{array}{l}\mathrm{D} \\
\mathrm{D}\end{array}$ \\
\hline $\begin{array}{l}\text { Balconies } \\
\text { Walls } \\
\text { Ceilings } \\
\text { Columns/beams } \\
\text { Handrails } \\
\text { Floorings }\end{array}$ & $\begin{array}{l}\text { D-s3,d1 } \\
\text { D-s3,d1 }\end{array}$ & $\begin{array}{l}\mathrm{D} \\
\mathrm{D} \\
\mathrm{D} \\
\mathrm{D}_{\mathrm{FL}}\end{array}$ & $\begin{array}{l}\text { C-s3,d1 } \\
\text { C-s3,d1 }\end{array}$ & $\begin{array}{l}\text { B-s2,d0 } \\
\text { B-s2,d0 } \\
\text { B-s2,d0 } \\
\text { D-s2,d2 } \\
D_{\mathrm{FL}}-\mathrm{s} 1\end{array}$ & $\begin{array}{l}\text { D-s3,d0 } \\
\text { D-s3,d0 } \\
\text { D-s3,d0 } \\
\text { D-s3,d0 } \\
\text { D }_{\mathrm{FL}}-\mathrm{s} 1\end{array}$ & $\begin{array}{l}\text { C-s2,d0 } \\
\text { B-s1,d0 } \\
\text { D-s2,d0 } \\
\text { D-s2,d0 } \\
\text { D }_{\mathrm{FL}}-\mathrm{s} 1\end{array}$ & $\begin{array}{l}\mathrm{C} / \mathrm{B} \\
\mathrm{C} / \mathrm{B} \\
(\mathrm{D}) \\
\left(\mathrm{D}_{\mathrm{FL}}\right) \\
\end{array}$ & $\begin{array}{l}\mathrm{D} \\
\mathrm{D} \\
\mathrm{D} \\
\mathrm{D} \\
\mathrm{D}_{\mathrm{FL}} \\
\end{array}$ \\
\hline $\begin{array}{l}\text { Access balconies } \\
\text { Walls } \\
\text { Ceilings } \\
\text { Columns/beams } \\
\text { Handrails } \\
\text { Floorings }\end{array}$ & $\begin{array}{l}\text { D-s1,d0 } \\
\text { D-s1,d0 } \\
\text { C }_{\mathrm{FL}-\mathrm{s} 1^{1)}}\end{array}$ & $\begin{array}{l}\mathrm{A} \\
\mathrm{A} \\
\mathrm{A} \\
\mathrm{A}_{\mathrm{FL}}\end{array}$ & & $\begin{array}{l}\text { B-s2,d0 } \\
\text { A2-s1,d0 } \\
\text { B-s2,d0 } \\
\text { D-s2,d2 } \\
\text { D }_{\text {FL-s1 }}\end{array}$ & $\begin{array}{l}\text { B-s3,d0 } \\
\text { B-s3 d0 } \\
\text { D-s3,d0 } \\
\text { A2-s1,d0 } \\
\text { D }_{\text {FL-s1 }}\end{array}$ & $\begin{array}{l}\text { B-s1,d0 } \\
\text { B-s1,d0 } \\
\text { D-s2,d0 } \\
\text { D-s2,d0 } \\
\text { C }_{\mathrm{FL}}-\mathrm{s} 1\end{array}$ & $\begin{array}{l}\text { B-s3,d2 } \\
\text { B-s3,d2 } \\
\text { (D) } \\
\left(D_{\mathrm{FL}}\right)\end{array}$ & $\begin{array}{l}\mathrm{D} \\
\mathrm{D} \\
\mathrm{D} \\
\mathrm{D} \\
\mathrm{D}_{\mathrm{FL}}\end{array}$ \\
\hline
\end{tabular}

${ }^{1)} \mathrm{D}_{\mathrm{FL}}$ if maximum 3 floors.

2) 1 . floor B-s2,d0.

3) SP Fire 105 (large scale test) criteria needs to be fulfilled.

4) 1 . floor $\mathrm{A} 2-\mathrm{s} 1, \mathrm{~d} 0$.

5) $\mathrm{D}$-s2,d0 when the building is sprinklered.

( ) Assumed requirement levels.

\section{Requirements for fire protection}

Fire safety of balconies is mainly based on fire resistance and reaction to fire requirements. In the group of countries included in this study there are not usually fire protection requirements for balconies concerning protective coverings or automatic extinguishing. However, in Finland $\mathrm{K}_{2} 10$ or $\mathrm{K}_{2} 30$ coverings are required to be used if the balcony is not sprinklered. Also in some other countries sprinklers can reduce the required performance level, mainly reaction to fire class. In addition, there may be also requirements concerning ability to limit spread of fire and prevent parts falling down.

\section{Effects of balcony glazing}

In some countries, the requirements are different for balconies with glazing (e.g. balcony will be interpreted as part of the apartment and requirements will follow accordingly). As an example in Norway balcony is considered to be indoor area when less than $50 \%$ of the upper part of balcony is open. In Sweden double glazing means that balcony is considered to be as part of the apartment.

\section{Use of balconies for evacuation}

There are significant differences between the countries of this study concerning definitions of escape routes and emergency exits. According to the responses received it can be concluded that balconies 


\section{MATEC Web of Conferences}

can be used in most cases for evacuation and this may cause more stringent requirements to be applied (according to access balcony requirements or general exit requirements).

\section{FIRE EXPOSURES ON FACADE AND PROTECTION METHODS FOR EAVES}

The needed means of protection of eaves are dependent on fire exposures on facade and possible consequences of fire spreading through eaves. The response and performance of eaves have been analysed under scenarios which are relevant to occur in practice for different types of buildings. If the building is sprinklered there is no flashover room fire causing a major exposure on the facade and external fire sources may be the origin of ignitions on facades. Common objects of causing these hazards are different type of waste, motor vehicles, shelters, etc. Experimental data has clearly shown that external ignitions will cause less severe exposures on wooden facade than flashover room fires [2-4].

The evaluation covered wooden facades (at least D-s2, d2 class) and facade claddings made of nearly non-combustible materials (at least B-s1/s2, d0 class) comparing effects on fire spread in cases of sprinklered and non-sprinklered buildings. The study aimed to evaluate the needs for protection of eaves in relation to consequences under different fire exposure conditions. The following cases were considered:

- Ventilated eaves

- Use of fire dampers and closing valves

- Compensation of requirements for eaves by fire performance of load bearing roof structures (case by case application).

\section{Effect of wooden facade on fire exposure}

Effect of wooden facade on fire exposure can be assessed utilizing results experimental series of facade tests made at VTT [2-4] and an earlier performance based approach of wooden facades [5]. Main conclusions of the experiments are summarized below.

When using D-s2, d2 class wood products or B-s1/s2, d0 class claddings in buildings up to 8 floors ( 8 floors is the prescriptive limit for use of wood in facades in Finland) the fire exposure for eaves can be estimated as follows:

- In a sprinklered building facade fire starts from an external ignition source. Fire exposure on facade is substantially lower than in case of flashover room fire.

- When using wooden facade claddings fire is spreading mainly through flame contact because the heat radiation is quite small (less than $10 \mathrm{~kW} / \mathrm{m}^{2}$ at a distance of more than 0.5 meters from the burning area, and not more than $20 \mathrm{~kW} / \mathrm{m}^{2}$ at the base of the flame). Fire spreading one floor height (around 3 meters) on the surface of the facade will take 10-15 minutes.

- B-s1/s2, d0 products as claddings will not spread fire practically at all under exposures from external ignition sources.

- In a non-sprinklered apartment building a flashover room fire can cause the following exposures on the facade and under the eaves (if the fire starts in the upper parts of the building):

- Wooden facade: Maximum of fire exposure level about $100 \mathrm{~kW} / \mathrm{m}^{2}$.

○ B-s1/s2, d0 class cladding: Maximum fire exposure about $70 \mathrm{~kW} / \mathrm{m}^{2}$.

The response of eaves and the consequences caused by different types of facade fires can be described as follows:

- Sprinklered building - start of fire from an external ignition source:

- Wooden facade (spreading by flame contact, heat radiation $<20 \mathrm{~kW} / \mathrm{m}^{2}$ ). 
$1^{\text {st }}$ International Seminar for Fire Safety of Facades, Paris (France), 2013

- Closed eaves (EI 30 or equivalent): Fire does not spread to the attic cavity in less than 30 minutes.

- Open eaves: Fire may spread to the attic. Structure of eaves affects the flame spread to the attic cavity.

- B-s1/s2, d0 class cladding - open eaves: Probability of fire spread to the attic cavity is very low.

- Non-sprinklered building - exposure from a flashover room fire.

- Wooden facade: Maximum fire load about $100 \mathrm{~kW} / \mathrm{m}^{2}$.

- Closed eaves (EI 30 or equivalent): Fire does not spread to the attic cavity in less than 30 minutes.

- Open eaves: Fire may spread to the attic cavity immediately (structure of eaves may delay spread of fire).

- B-s1/s2, d0 class cladding - open eaves: Fire may spread to the attic cavity immediately because of the exposure level of about $70 \mathrm{~kW} / \mathrm{m}^{2}$ (structure of eaves may delay spread of fire).

\section{ALTERNATIVES FOR TOTALLY CLOSED EAVES}

Fully closed eaves are the simplest way to prevent spreading of fires to the attic and roof structures. However, this may not always be practical (e.g. because of needs for ventilation). Substitutive protection solutions for completely closed eaves or compensation conditions for protective means can be the following: Use of fire dampers and closing valves, use of ventilated eaves with specific fire preventive construction, and compensation of requirements for eaves by more performance level for roofs (casespecific applications).

\section{Use of fire dampers}

Ventilation at eaves requires only a limited size of vents. Thus fire dampers and closing valves specially designed and approved for this purpose can be used to prevent fire spread. Fire dampers installed on the eaves or on the facade wall just below the eaves need to meet the EI 30 requirements and method of installation must fulfil the end-use conditions according to the classification.

\section{Ventilated eaves}

In an earlier study the means to delay fire spread through a ventilated facade to attic cavity has been studied [6]. A solution which was found to slow the spread of the fire into the attic cavity for 10-15 minutes was proposed as a result of that study. In normal service conditions, air flow is taking care of the ventilation in the void space as shown in Figure 1a. In the event of fire (= flames under the eave) the air flow direction changes to the opposite because of under-pressure formed by the flames and/or hot gases passing the gutter structure of Figure $1 \mathrm{~b}$.

New development based on the above described principles includes EI 30 protection under the eaves according to Figure 1. Using this type of solution, the fire spread from facade to attic cavity can be expected to be delayed at least 30 minutes in a building with wooden facade.

\section{Compensation of requirements for eaves by protection of roof structures}

According to the Finnish building regulations of fire safety, compliance with the requirement can be verified in case-by-case applications on performance basis. This approach for the eaves problem can be used as follows: The attic cavity is not sprinklered, but the fire exposure (and fire load) can be estimated 


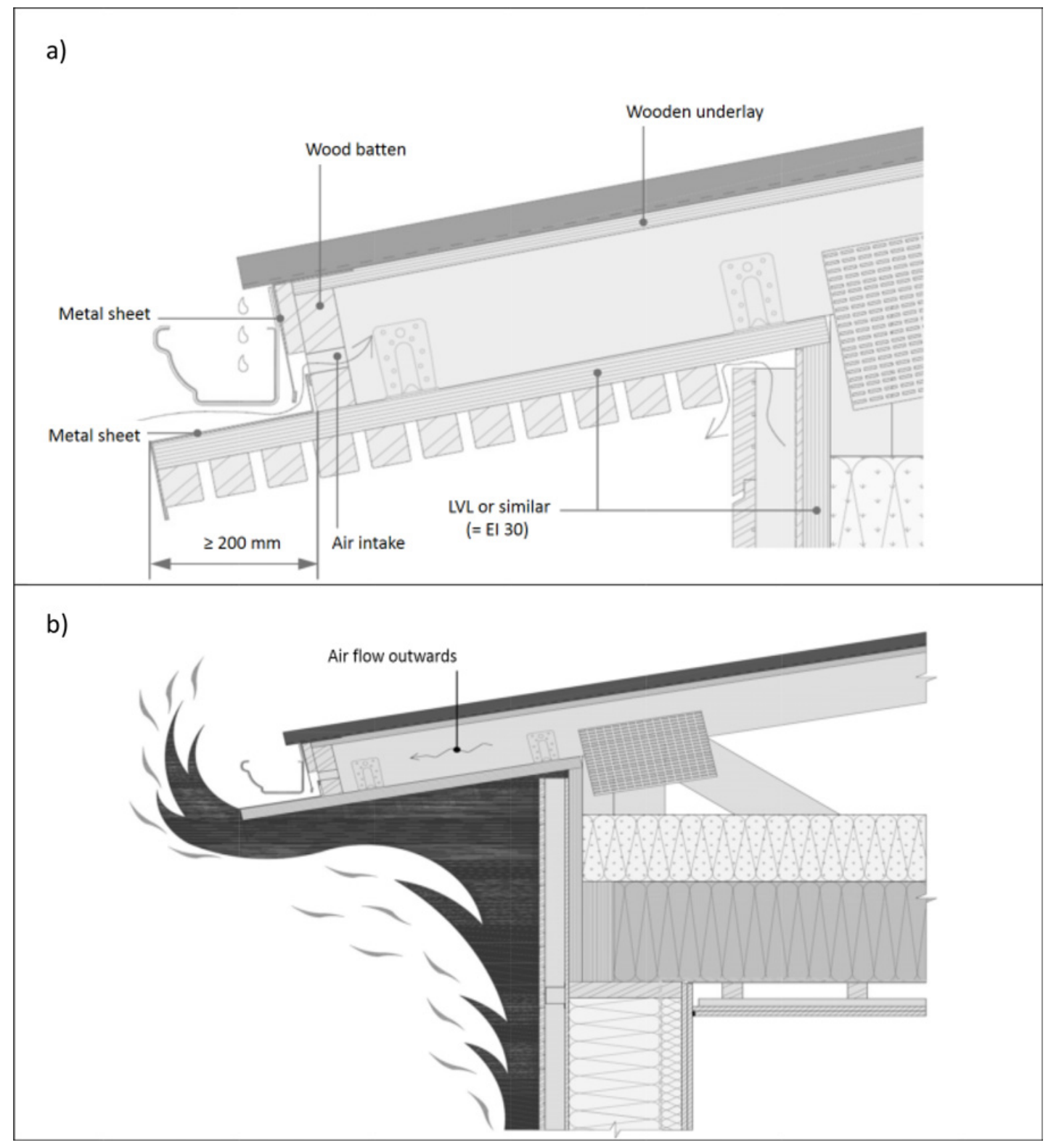

Figure 1. Solution principles for ventilated eaves: a) ventilation in normal service conditions and b) airflow direction under fire conditions [7].

to be substantially lower than in rooms of a non-sprinklered building (similar assumption is valid for balconies, for which the fire resistance requirement is half of the requirement of load-bearing structures of the building).

To ensure structural integrity for a required time (REI 60 required between fire compartments according to Finnish regulations for timber framed building with 3-8 floors) the following may be required if the eaves are open and the load bearing roof structures are made of materials not fulfilling at 
least class A2-s1, d0 requirements: Protection of attic cavity floor with $\mathrm{K}_{2} 30$ class covering fulfilling at least B-s1, d0 reaction to fire class.

\section{SUMMARY}

Fire safety aspects and requirements of wooden balconies and access balconies were reviewed in nine countries. The analysis concerned 3-8 storey apartment buildings with timber frame (and to some extent also office buildings), including the following issues: Assumptions on fire exposure, fire resistance requirements, reaction to fire requirements, possible requirements concerning protective means and use of balconies as exit routes in a fire situation.

In many of the countries there are no specific assumptions for fire loads in buildings. However, in some countries Eurocode (EN 1991-1-2) values are used as a basis of fire load design values with nationally modified values. Effect of sprinkler systems may be taken into account by means of reduction factors. For the load bearing structures of the studied building types R60 requirement applies generally. For balconies fire resistance requirements vary between R0 and R60, and the requirements are usually the same for sprinklered and non-sprinklered buildings. For access balconies fire resistance requirements are generally more stringent than for balconies, ranging between R30 and R90.

Use of untreated (=no fire retardant treated) wood is usually possible on facades up to $4-7$ floors or even more if relevant proof has been demonstrated (e.g. with large scale testing). On the first floor non-combustible or nearly non-combustible claddings may be required. Reaction to fire requirement of balconies is commonly $\mathrm{D}$ (or $\mathrm{C}$ ) level. For balcony floors typical requirement is $\mathrm{D}_{\mathrm{FL}}$. For access balconies reaction to fire requirements are generally more stringent (walls and ceilings usually of B level) than for balconies.

For most countries there are no fire protection requirements for balconies concerning protective coverings or automatic extinguishing. In some countries, the requirements are different for balconies with glazing (e.g. balcony will be interpreted as part of the apartment and requirements will follow accordingly). Balconies can be used in most cases for evacuation which may cause more stringent requirements to be applied.

In another study the effects of eaves to fires on facade were analysed. The response can be described according to the scenarios which are relevant to occur in practice for different types of buildings. The building may be sprinklered or not, the facade cladding can be made of wood (D-s2, d2 class) or at least nearly non-combustible materials (B-s1/s2, d0 class) and the eaves can be closed (EI 30) or open for ventilation of attic cavity.

Substitutive protection solutions for completely closed eaves and compensation conditions for protective means can be the following: Use of fire dampers and closing valves, use of ventilated eaves with specific fire preventive construction, and compensation of requirements for eaves by additional protection methods for roof structures (case-specific applications).

The financial support of Finnish Wood Research Ltd is gratefully acknowledged. All the experts who answered the questionnaire on fire safety regulations of balconies and access balconies are gratefully thanked on their valuable contribution.

\section{References}

[1] EN 1991-1-2:2002. Eurocode 1: Actions on structures - Part 1-2: General actions - Actions on structures exposed to fire. CEN 2002. 
[2] Hakkarainen, T., Oksanen, T. \& Mikkola, E. Fire safety of wooden facades for sprinklered multistorey houses. Espoo. Technical Research Centre of Finland, 1996. 29 p. + app. 16 p. VTT Research Notes 1736. (In Finnish)

[3] Hakkarainen, T., Oksanen, T. \& Mikkola, E. Fire behaviour of facades in multi-storey wood-framed houses. Espoo: Technical Research Centre of Finland, 1997. 42 s. + app. 16 p. VTT Research Notes 1823. (In Finnish)

[4] Hakkarainen, T. \& Oksanen, T. Fire safety assessment of wooden facades. Fire and Materials, 2002. Vol. 26, pp. 7-27.

[5] Korhonen, T. \& Hietaniemi, J. Fire Safety of Wooden Facades in Residential Suburb Multi-Storey Buildings. Espoo 2005. Technical Research Centre of Finland. 66 p. + app. 40 p. VTT Working Papers 32.

[6] Hietaniemi, Jukka, Hakkarainen, Tuula, Huhta, Jaakko, Jumppanen, Ulla-Maija, Kouhia, Ilpo, Vaari, Jukka \& Weckman, Henry. Fire safety of cavity spaces. Prevention of fire spread in building voids. Espoo 2003, VTT Building and Transport. 168 p. + app. 52 p. VTT Research Notes 2202. (In Finnish.)

[7] Fire preventive eaves. Puuinfo, Tekninen tiedote 14.6.2012. http://www.puuinfo.fi/sites/default/ files/content/rakentaminen/suunnitteluohjeet/paloraystas/paloraystas.pdf (In Finnish) 